\title{
Immunochemical Gharacterization of the Antigen Recognized by the Murine Monoclonal Antibody A7 against Human Colorectal Cancer
}

\author{
Kazuya Kitamura, Toshio Takahashi, Toshiharu \\ Yamaguchi, Takashi Yokota, Akinori Noguchi, \\ Takashi Amagai* and Jiro Imanishi* \\ The First Department of Surgery and *Department of \\ Microbiology, Kyoto Prefectural University of Medicine, \\ Kyoto 465
}

\begin{abstract}
Kitamura, K., Takahashi, T., Yamaguchi, T., Yokota, T., Noguchi, A., Amagai, T. and Imanishi, J. Immunochemical Characterization of the Antigen Recognized by the Murine Monoclonal Antibody A7 against Human Colorectal Cancer. Tohoku J. Exp. Med., 1989, 157 (2), 83-93 — The nature of the antigen recognized by the murine monoclonal antibody A7 (Mab A7) against human colorectal carcinoma was investigated using immunochemical and biochemical techniques. Binding activity of ${ }^{125} \mathrm{I}$-labeled Mab A7 was examined using various human cancer cell lines. Mab A7 gave the highly specific binding to colon cancer cell lines, SW1116 and WiDr, and gave only a very weak or no reactivity to gastric cancer cell lines, pancreas cell lines or lung cancer cell lines. SDS-polyacrylamide gel electrophoresis (SDS-PAGE) and immunoblotting of the extractable antigen from SW1116 showed a single band at approximately 45,000 dalton formed by ${ }^{125}$ I-labeled Mab A7. Treatment of SW1116 with sodium periodate, pronase and ficin resulted in the loss of antigenic activity. These data strongly suggest that the antigen recognized by Mab A7 is composed of glycoprotein. Competitive binding analysis to the surface of the colon cancer cell line using polyclonal anti-CEA and Mab A7 as well as immunoblotting analysis using monoclonal anti-CEA and Mab A7 suggested that the antigen recognized by Mab A7 was different from CEA. Moreover, this antigen was also found in surgical specimens of colorectal cancer patients and its molecular property was identical to the antigen extracted from SW1116. - monoclonal antibody A7; colon cancer associated antigen; immunochemical characterization of the antigen
\end{abstract}

In recent years, several monoclonal antibodies which react to colon cancer associated antigens have been produced (Kristensen et al. 1976; Herlyn et al. 1979 ; Colcher et al. 1981, 1985 ; Magnani et al. 1981 ; Firan et al. 1982 ; Hedin et al. 1982 ; Haskell et al. 1983 ; Lindholm et al. 1983 ; Thompson et al. 1983 ; Powel et al. 1984 ; Cristophe et al. 1986 ; Drewinko et al. 1986). We have also previously produced Mab A7 against human colon cancer (Kotanagi et al. 1986)

Received July 21, 1988; revision accepted for publication December 28, 1988. 
and have applied it clinically for the immunotargeting chemotherapy of colorectal cancer patients (Takahashi et al. 1988). However, the detailed characteristics of the antigen recognized by Mab A7 have not been classified yet. Therefore, the study was undertaken to investigate the molecular characteristics of the antigen recognized by Mab A7 using biochemical and immunochemical methods and to compare this antigen with carcinoembryonic antigen (CEA). Here we demonstrate that the antigen is a unique 45,000 dalton glycoprotein which is different from CEA and CEA-related antigens.

\section{Materials and Methods}

Preparation of antibody. Ascitic fluid was collected from BALB/c mice primed with 2, 6, 10, 14-tetramethyl-pentadecane (Sigma Chemical Co., St. Louis, MO, USA) which were injected with monoclonal antibody A7 producing hybridoma $\left(1 \times 10^{7}\right)$. Then Mab was isolated from the fluid by Protein A ligand column chromatography (Affi-Gel Protein A Monoclonal Antibody Purification System, MAPS, Bio-Rad) (Ey et al. 1978). Isolated Mab A7 was dialyzed against phosphate buffered saline (PBS) and stocked in a deep freezer $\left(-70^{\circ} \mathrm{C}\right)$. Anti-CEA monoclonal antibody (Mab anti-CEA), was kindly provided from Dr. Nishi (Hokkaido University, Sapporo). Anti-CEA polyclonal antibodies were purchased from Ventrex Lab. (Portland, ME, USA).

Cell lines and surgical specimens. Eight human cancer cell lines; human colon cancer cell lines, SW1116 and WiDr; human gastric cancer cell lines, MK-01 and AZ 521; human pancreatic adenocarcinoma cell lines, MIAPACA 2 and CAPAN 2; human lung cancer cell lines, A549 and SKMES 2 were used in this study. These cell lines were cultured in RPMI 1640 medium supplemented with $10 \%$ heat inactivated fatal calf serum (FCS). Colorectal cancer tissues from 24 patients and normal colonic mucosal tissues from 6 patients were obtained from surgical specimens and stocked in a deep freezer until use.

Cell membrane extracts. After 3 times washing of SW1116 with PBS, $0.5 \mathrm{ml}$ of extraction buffer (10 mM Tris-HCl, $\mathrm{pH} 7.2,0.15 \mathrm{M} \mathrm{NaCl}, 0.02 \% \mathrm{NaN}_{3} 0.5 \%$ Nonidet-40) (Cone and Marchalonis 1974) was added to the pelleted cells $\left(5 \times 10^{7}\right)$ and mixed using a Voltex mixer. The mixture was put on ice for $20 \mathrm{~min}$ and then centrifuged at 15,000 rpm for $20 \mathrm{~min}$. The supernate was carefully collected and stocked in a deep freezer.

Labeling procedure. Mab A7 and Mab anti-CEA were labeled with ${ }^{125}$ I (New England Nuclear, Boston, MA, USA) by the chrolamine T method (Greenwood et al. 1963). Briefly, $50 \mu \mathrm{l}$ of antibody $(1 \mathrm{mg} / \mathrm{ml})$ was mixed with $\mathrm{Na}{ }^{125} \mathrm{I}(600 \mu \mathrm{Ci})$ and $50 \mu \mathrm{l}$ of chrolamine $\mathrm{T}$ $(400 \mu \mathrm{g} / \mathrm{ml})$ for $15 \mathrm{sec}$. The radiolabeled reaction was stopped with $200 \mu$ l of $\mathrm{Na}_{2} \mathrm{~S}_{2} \mathrm{O}_{5}(400$ $\mu \mathrm{g} / \mathrm{ml}$ ). The mixture was applied onto anion exchange resin column (AG1-X4, 100-200 mesh, chloride form, Bio-Rad) to remove free iodine from the mixture. The elution fluid was transferred to a glass reservoir containing sodium azide at a final concentration of $0.1 \%$ and bovine serum albumin (BSA) at a final concentration of $1 \%$. Five $\mu \mathrm{l}$ of aliquot fluid was removed and the radioactivity in trichloro-acetic acid-insoluble fractions was counted. Specific activities of labeled Mab were 5 to $100 \mu \mathrm{Ci} / \mu \mathrm{g}$.

Direct antibody binding radioimmunoassay of cancer cell line. Target cells $\left(1 \times 10^{5}\right)$ were incubated with $100 \mu \mathrm{l}$ of ${ }^{125}$ I-labeled A7 Mab $\left(10^{5} \mathrm{cpm}\right)$ in PBS containing BSA for 1 $\mathrm{hr}$ at $4^{\circ} \mathrm{C}$. The cells were then washed 3 times with ice cold PBS and centrifuged for $5 \mathrm{~min}$ at $1,000 \mathrm{rpm}$. Then, pellets were transferred to tubes for gamma counting.

SDS-polyacrylamide gel electrophoresis (SDS-PAGE) and immunoblotting. Cell extracts of colon cancer cell lines, SW1116 and WiDr were subjected to SDS-PAGE (9\%) at 150 volt for $3 \mathrm{hr}$ (Laemmli 1970). The separated proteins on gel were electrically transferred to nitrocellulose membrane in blotting buffer (25 mM Tris-HCl, $\mathrm{pH} 8.0,192 \mathrm{mM}$ glycine, $20 \%$ methanol, $0.1 \%$ SDS) at $12 \mathrm{~mA}$ for $4 \mathrm{hr}$ (Towbin et al. 1979). For blocking, the paper 
sheet was then incubated in washing buffer (10 mM Tris-HCl, pH 7.5, $0.15 \mathrm{M} \mathrm{NaCl}, 0.03 \%$ Tween 20) containing $2 \%$ BSA for 30 min at room temperature. After blocking, the paper was placed in a vinyl bag containing ${ }^{125}$ I-labeled Mab A7 $\left(10^{6} \mathrm{cpm}\right)$ for $1 \mathrm{hr}$. The paper was washed 5 times with washing buffer and exposed to $\mathrm{Fuji}$-ray film at $-70^{\circ} \mathrm{C}$ for 3 days. Detection of the insoluble tumor antigen in surgical specimens were performed in the same manner. In some experiments, ${ }^{125}$ I-labeled Mab anti-CEA $\left(10^{6} \mathrm{cpm}\right)$ was used instead of Mab A7.

Enzyme treatment. Pronase, ficin, glucosidase, galactosidase, neuraminidase and sodium periodate were utilized. Pronase, glucosidase and galactosidase were purchased from Sigma (St. Louis, MO, USA). Sodium periodate was purchased from Nakarai Chemical Ltd. (Kyoto). Enzyme treatment of cells were done as follows (Malaya et al. 1984). Cultured SW 1116 cells $\left(5 \times 10^{5}\right)$ were treated with $0.1 \%$ trypsin containing $0.05 \%$ EDTA in PBS. The cells wore harvested and washed with RPMI. The cells were preincubated for $2 \mathrm{hr}$ at $37^{\circ} \mathrm{C}$ in RPMI containing $10 \% \mathrm{FCS}$ and then the enzyme treatment were performed. Pronase, sodium periodate, glucosidase, and galactosidase digestions were carried out in PBS, and neuraminidase digestion was carried out in $0.1 \mathrm{M}$ acetate buffer $\mathrm{pH} 5.0$. All digestions were carried out at $37^{\circ} \mathrm{C}$ for $2 \mathrm{hr}$. After 3 washings with PBS, digested cells were incubated in ${ }^{125} \mathrm{I}$-labeled Mab A7 $\left(10^{6} \mathrm{cpm}\right)$ for $1 \mathrm{hr} 4^{\circ} \mathrm{C}$. The cells were then washed 3 times with PBS and transferred to tubes for gamma counting. Enzyme treatment of membrane fractions were done as follows. Membrane fractions containing $1 \mathrm{mg}$ protein were incubated with enzymes as previously described. Membrane fractions digested with enzyme were then subjected to SDS-PAGE and immunoblotting prior to autoradiography.

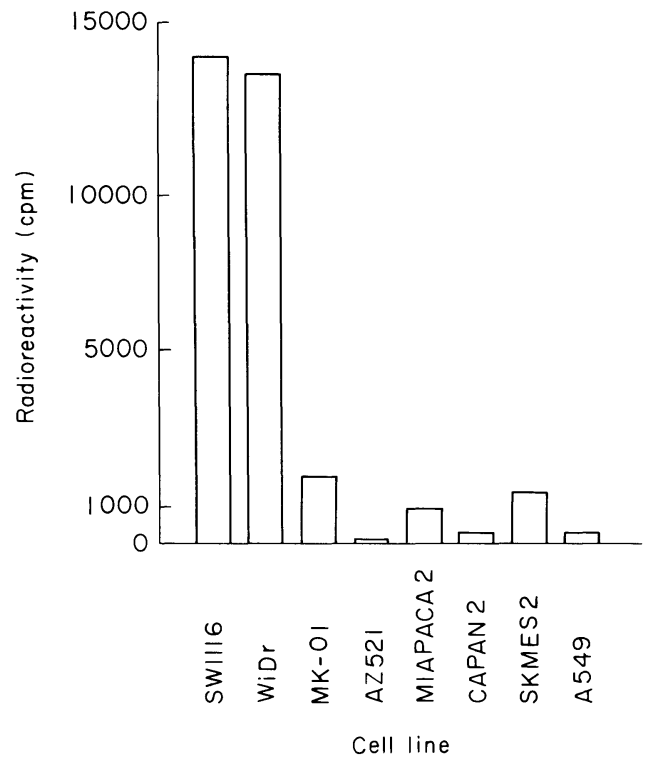

Fig. 1. Reactivity of ${ }^{125} \mathrm{I}$-labeled Mab A7 to a panel of cancer cell line.

Target cells $\left(1 \times 10^{5}\right)$ were incubated with $100 \mu$ l of ${ }^{125}$ I-labeled Mab A7 $\left(10^{5}\right.$ $\mathrm{cpm}$ ) for $1 \mathrm{hr}$ at $4^{\circ} \mathrm{C}$. The cells were then washed 3 times with PBS. Results are expressed as cpm of ${ }^{125} \mathrm{I}$-labeled Mab A7 bound to target cell lines.

Target cells were as follows :

SW1116 and WiDr, colon cancer cell lines;

MK-01 and AZ521, gastric cancer cell lines;

MIAPACA2 and CAPAN2, pancreas cancer cell lines;

SKMES2 and A549, lung cancer cell lines. 
Detection of CEA antigenic activity in SW1116. Cells $\left(5 \times 10^{5}\right)$ were incubated in ${ }^{125}$ I-labeled Mab anti-CEA solution $\left(10^{5} \mathrm{cpm}, 1 \mathrm{hr}, 4^{\circ} \mathrm{C}\right)$. After 3 washings with PBS, radioactivities of cell pellets were measured by a gamma counter.

Competitive binding of Mab $A 7$ with anti-CEA on SW1116. SW1116 $\left(5 \times 10^{5}\right)$ was firstly incubated in anti-CEA solution (polyclonal antibody, $\times 10$ ) for $2 \mathrm{hr}$ at $4^{\circ} \mathrm{C}$ and followed by incubation with ${ }^{125}$ I-labeled Mab A7 $\left(10^{5} \mathrm{cpm}\right)$. Alternatively cells $\left(5 \times 10^{5}\right)$ were firstly incubated with Mab A7 $(10 \mu \mathrm{g})$ for $2 \mathrm{hr}$ at $4^{\circ} \mathrm{C}$ and secondary incubated with ${ }^{125}$ I-labeled Mab anti-CEA $\left(10^{5} \mathrm{cpm}\right)$.

Detection of the extractable tumor antigen in surgical specimens. Colorectal cancer tissues from 24 patients and normal colon mucosal tissues from 6 patients were mechanically dissociated with a scalpel into small fragments and put in ertraction buffer containing $0.5 \%$ NP40. The fragments in extraction buffer were homogenized by ultrasonic homogenizer and centrifuged at $15,000 \mathrm{rpm}$ for $20 \mathrm{~min}$. Protein concentration in tumor extracts was measured by dye binding assay (protein assay kit, Bio-Rad). One mg of extractable protein in tumor extracts were subjected to SDS-PAGE and immunoblotting in the previously described method.

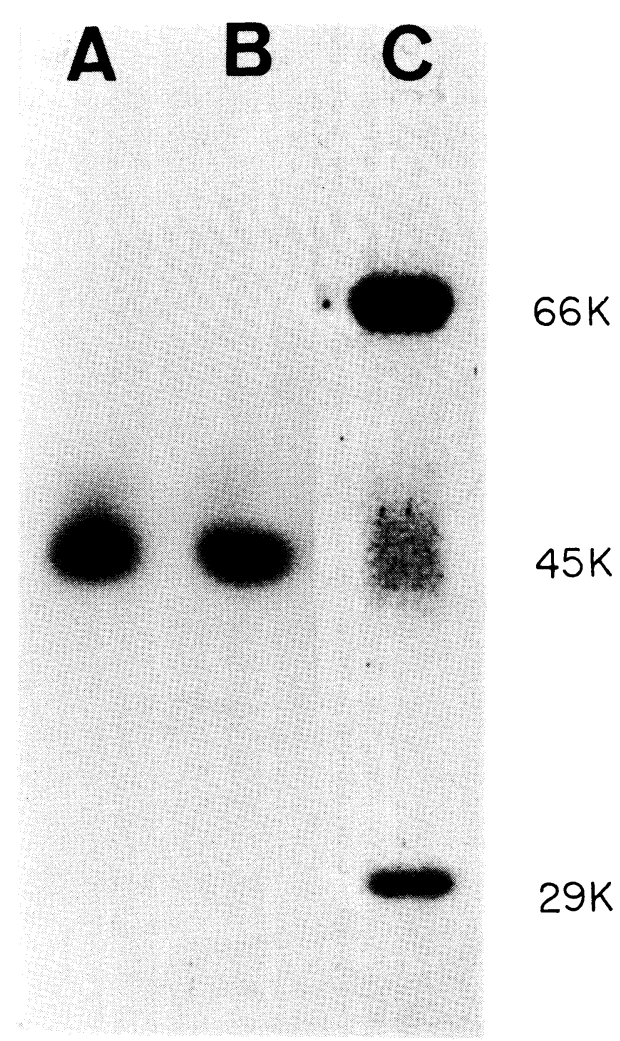

Fig. 2. SDS-PAGE and immunoblotting of the antigen recognized by Mab A7. Cell extracts were subjected to SDS-PAGE ( $9 \%$ gel). The separated proteins were transferred to nitrocellulose membrane. The paper sheet was incubated with ${ }^{125}$ I-labeled Mab A7 and then subjected to autoradiography.

lane A : the antigen from SW 1116.

lane $\mathrm{B}$ : the antigen from $\mathrm{WiDr}$.

lane $\mathrm{C}$ : molecular weight marker. 


\section{Results}

Reactivity of Mab A7 to a panel of tumor cell lines. The immunoreactivity of Mab A7 was analyzed by an antibody binding assay on a panel of human cancer cell lines, i.e., colon cancer cell lines (SW1116 and WiDr), gastric cancer cell lines (MK-01 and AZ521), pancreas cancer cell lines (MIAPACA 2 and CAPAN 2) and lung cancer cell lines (SKMES 2 and A549). As shown in Fig. 1, Mab A7 gave a highly positive binding to human colon cancer cell lines SW1116 and WiDr. On the other hand, MK-01, MIAPACA 2 and SKMES 2 exhibited low reactivity with Mab A7. Significant binding was not detected in AZ521, CAPAN 2 and A549. These data indicate that Mab A7 can bind specifically to colon cancer cell lines in vitro.

Determination of molecular weight of the antigen recognized by Mab A7. To determine molecular weight of the antigen recognized by Mab A7, membrane extracts from SW1116 and WiDr were subjected to SDS-PAGE and immunoblotting using ${ }^{125}$ I-labeled Mab A7. Mab A7 gave a single band at approximately 45,000 dalton in both the cases (Fig. 2).

Determination of the biochemical nature of the antigen. The nature of the antigenic determinant was biochemically investigated. SW1116 cells were treated with pronase, ficin, sodium periodate, galactosidase, glucosidase and neuraminidase. After the treatments, the antigenic activities were studied by using

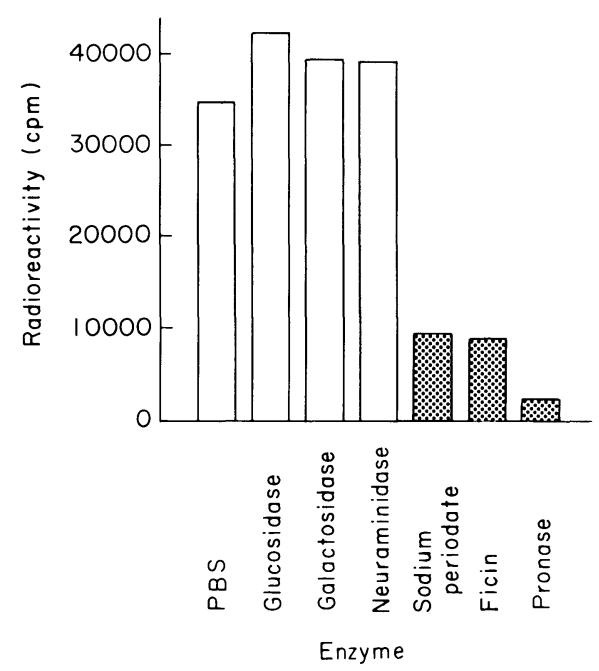

Fig. 3. Effects of chemical and enzymatic treatments on binding activity of ${ }^{125}$ I-labeled A7 to SW1116.

Target cells $\left(5 \times 10^{5}\right)$ were incubated with various enzyme for $2 \mathrm{hr}$ at $37^{\circ} \mathrm{C}$. The cells were then incubated with ${ }^{125} \mathrm{I}$-labeled $\mathrm{A} 7$ for $1 \mathrm{hr}$ at $4^{\circ} \mathrm{C}$ and washed 3 times with PBS. Results are expressed as cpm of ${ }^{125}$ I-labeled Mab A7 bound to cell pellets. 
binding assay of lebeled Mab A7. The results were shown in Fig. 3. Pronase, ficin and sodium periodate digestions showed a decrease of antigen activity. On the other hand, neuraminidase, galactosidase and glucosidase digestion had no effect on the activity. The nature of the antigen was also investigated by the enzyme digestions and chemical treatment of extracted membrane fraction from SW 1116. After the treatment, the extracts were subjected to SDS-PAGE and immunoblotting. The results also indicate that the antigen reacted to Mab A7 was sensitive to pronase and sodium periodate (Fig. 4). These results suggest that the antigen recognized by Mab A7 is non-sialilated glycoprotein.

Comparison of the antigen recognized by Mab A7 with CEA. Reactivity of Mab A7 to CEA was investigated by using antibody binding assay and immunoblotting. SW1116 cells were pretreated with either polyclonal anti-CEA or Mab A7 and tested for the binding activity of ${ }^{125}$ I-labeled Mab A7 or ${ }^{125}$ I-labeled anti-CEA. As shown in Fig. 5, Mab A7 gave positive binding to SW1116 prein-

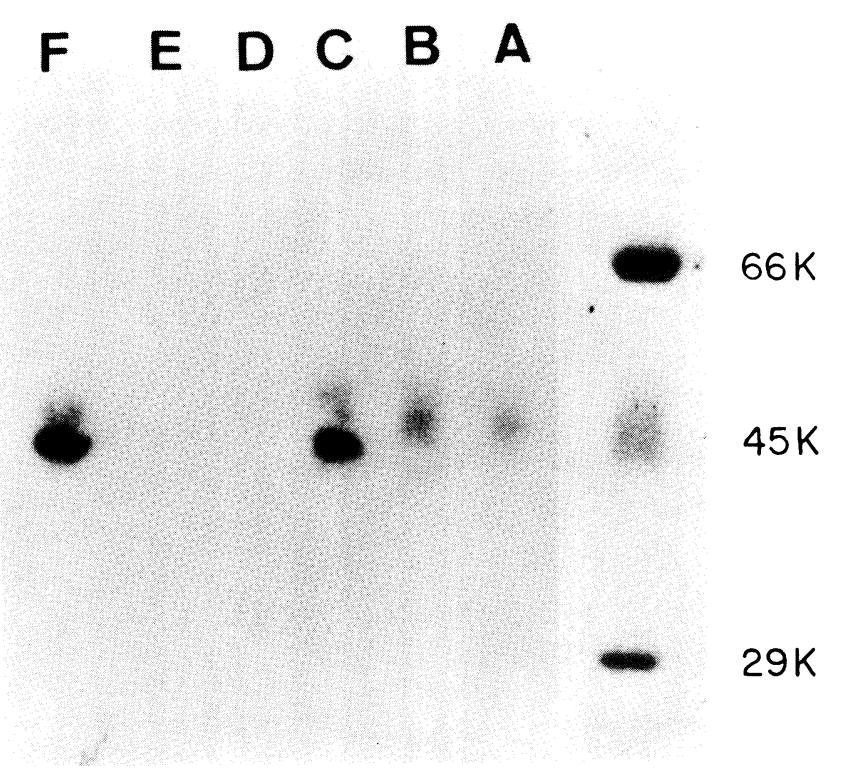

Fig. 4. SDS-PAGE and immunoblotting of the antigen treated by pronase and sodium periodate.

Membrane fractions containing $1 \mathrm{mg}$ of protein were incubated with pronase and sodium periodate. Enzyme-digested membrane fractions were subjected to SDS-PAGE and immunoblotting. Results show the remarkable loss of antigenic activity in lane $\mathrm{A}$ to $\mathrm{E}$ as compared with lane $\mathrm{F}$.

lane A: sodium periodate $100 \mathrm{mM}$.

lane B : sodium periodate $50 \mathrm{mM}$.

lane $\mathrm{C}$ : sodium periodate $10 \mathrm{mM}$.

lane $\mathrm{D}$ : pronase $500 \mu \mathrm{g}$.

lane $\mathrm{E}:$ pronase $100 \mu \mathrm{g}$.

lane F : PBS (control). 


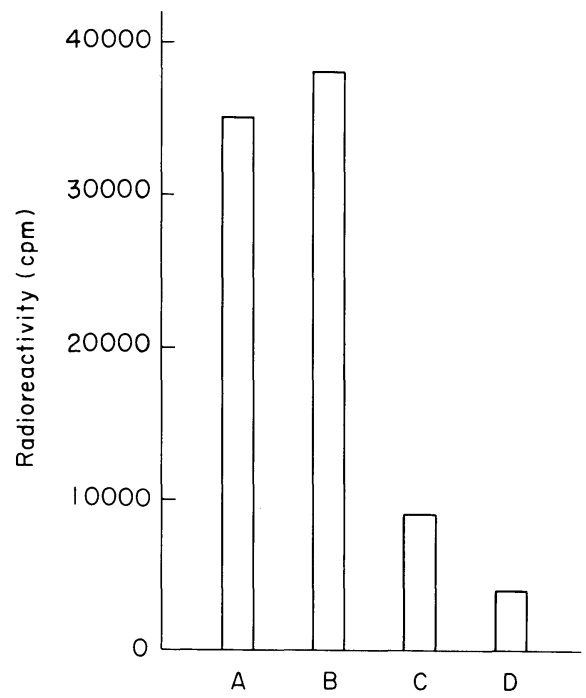

Fig. 5. Competing binding assay of Mab A7 with anti-CEA and vice vasa on SW1116.

Target cells $\left(5 \times 10^{5}\right)$ were firstly incubated with each antibody for $1 \mathrm{hr} 4^{\circ} \mathrm{C}$. Cells were then incubated with ${ }^{125}$ I-labeled monoclonal antibodies and washed with PBS. Results are expressed as cpm of ${ }^{125} \mathrm{I}$-labeled Mab A7 or ${ }^{125} \mathrm{I}$ labeled anti-CEA.

A : SW1116 was firstly incubated with anti-CEA (polyclonal) and then incubated with ${ }^{125}$ I-labeled Mab A7.

B : SW1116 was firstly incubated with Mab A7 and then incubated with ${ }^{125}$ I-labeled Mab anti-CEA.

C: SW1116 was firstly incubated with anti-CEA (polyclonal) and then incubated with ${ }^{125}$ I-labeled Mab anti-CEA.

D: SW1116 was firstly incubated with Mab A7 and then incubated with ${ }^{125}$ I-labeled Mab A7.

cubated with anti-CEA polyclonal antibody. Similarly in the reverse experiment, Mab anti-CEA gave positive binding to SW1116 preincubated with Mab A7. The cell extract of SW1116 was subjected to SDS-PAGE and blotting on nitrocellulose membrane. Then cross reactivity of the antigen recognized by Mab A7 and CEA was examined by the reaction with labeled Mab A7 or Mab anti-CEA. Representative results were shown in Fig. 6. ${ }^{125}$ I-labeled Mab A7 formed only a single band at 45,000 dalton, whereas ${ }^{125}$ I-labeled Mab anti-CEA formed only a single band at 180,000 dalton (Fig. 6). These results suggest that the antigen recognized by Mab A7 is completely different from CEA.

Detection of the antigen in surgical tumor specimens by using immunoblotting. Using immunoblotting we investigated whether the antigens extracted from tumor tissue were identical to the antigen extracted from cell line SW1116. The tumor extracts were subjected to SDS-PAGE and immunoblotting. The bands at approximate 45,000 daltons seen as the antigen of SW1116 were detected in all 


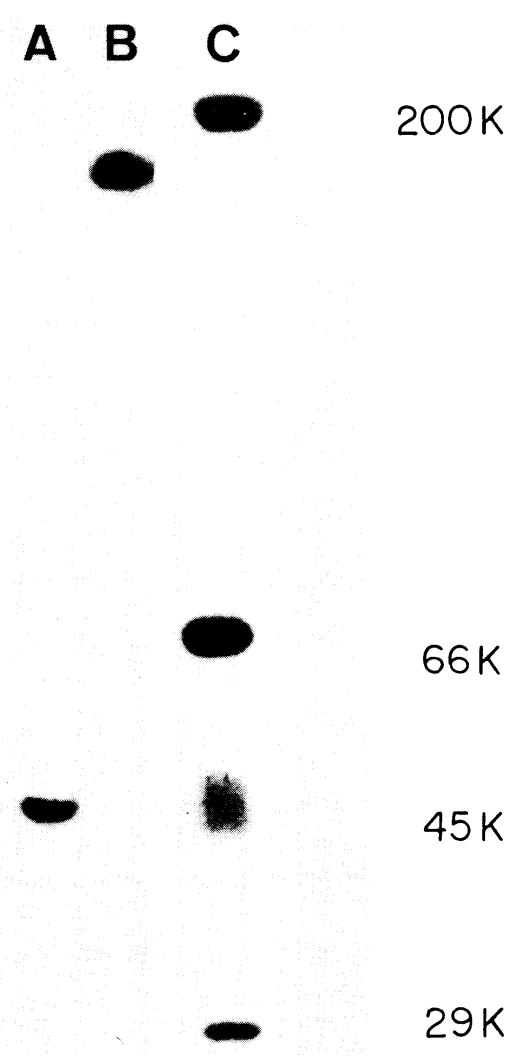

Fig. 6. SDS-PAGE and immunoblotting of the cell extract containing the antigen recognized by Mab A7 and Mab anti-CEA.

Membrane extract from SW1116 was subjected to SDS-PAGE and immunoblotting. After electroblotting, nitrocellulose membrane were incubated with ${ }^{125}$ I-labeled Mab A7 or ${ }^{125}$ I-labeled Mab anti-CEA. ${ }^{125} \mathrm{I}$-labeled Mab A7 detected only a band of $45 \mathrm{kd}$ and ${ }^{125} \mathrm{I}$-Mab anti-CEA detected a single band of $180 \mathrm{kd}$.

lane $\mathrm{A}$ : the antigen recognized by Mab A7.

lane $\mathrm{B}$ : the antigen recognized by anti-CEA.

lane $\mathrm{C}$ : molecular marker.

colorectal carcinomas (Fig. 7) and two of 6 normal mucosal tissues. However, density of positive bands of normal colonic mucosa were low.

\section{Discussion}

In the previous study, we studied the specificity of Mab A7 using ELISA technique and found that the antibody reacted specifically to colon cancer cell lines (SW 1116 and SW 1083), but not to breast cancer cell line (MCF-7), kidney cancer cell line (SK-RC-9), lung cancer cell line (SK-MES-1), bladder cancer cell line (T-24) and fetal fibroblast cell line (HEL) (Kotanagi et al. 1986). In the 


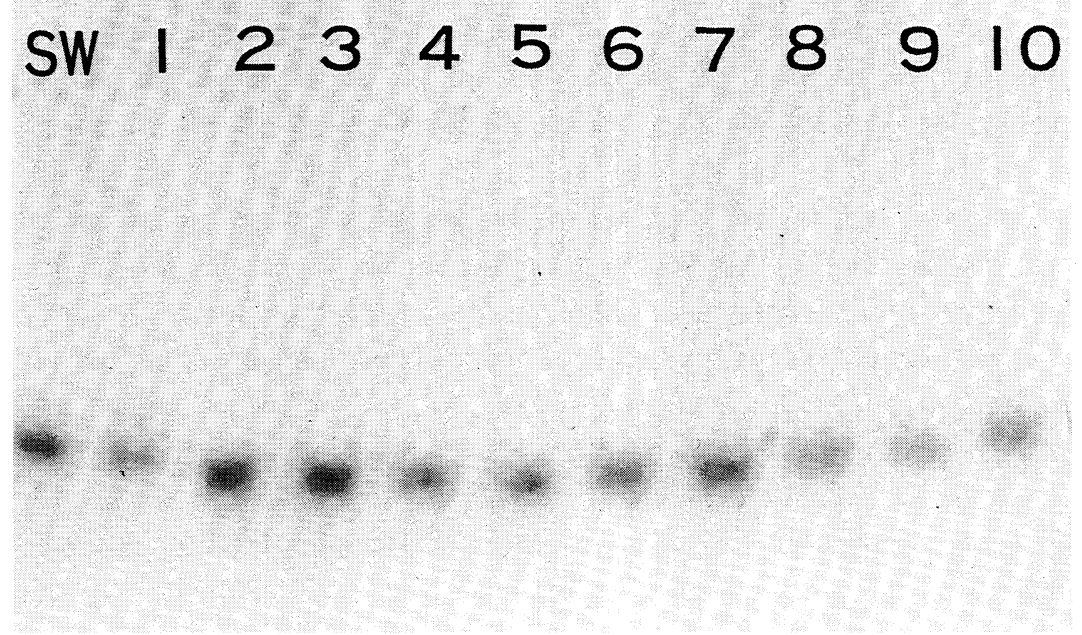

Fig. 7. SDS-PAGE and immunoblotting of the extractable antigen in surgical specimens.

Membrane fractions from each tumor were subjected to SDS-PAGE immunoblotting. Antigen band of $45 \mathrm{kd}$ was detected in all tumor specimens and those densities express the concentration of the antigen recognized by Mab A7 in tumors.

SW : colon cancer cell line SW1116.

1-10: colorectal cancer patients.

present study, we performed direct antibody binding radioimmunoassay to detect more precisely the reactivity of Mab A7 to various cancer cell lines. The results showed that high binding of Mab A7 was observed in colon cancer cell lines, but not in others. Various monoclonal antibodies which specifically react to colon cancers have been reported by several authors (Kristensen et al. 1976; Herlyn et al. 1979 ; Colcher et al. 1981 ; Magnani et al. 1981 ; Firan et al. 1982). Therefore, biochemical characterization of the colon cancer specific-antigen is necessary to clarify the difference of epitope specificity.

We showed that Mab A7 reacts with a molecule having a molecular weight of 45,000 daltons by using SDS-PAGE and immunoblotting. Molecular size of human colon cancer-associated antigens was reported by various authors (Magnani et al. 1981 ; Drewinko et al. 1984 ; Colcher et al. 1985). The colorectal cancerassociated antigen reported here is different from these antigens. Recently, Cristophe et al. (1986) reported the monoclonal antibody LD-1 which reacts with 41,000 dalton glycoprotein (Cristophe et al. 1986). The difference of the antigen recognized by Mab A7 from the antigen recognized by LD-1 has not yet been assessed.

Enzymatic and chemical treatment of the antigen recognized by Mab A7 were undertaken to better understand the nature of the ancigen. Not only the antigen 
expressed on viable cells but also the antigen extracted from the cells was similarly sensitive to pronase and sodium periodate. The results suggest that the antigen recognized by Mab A7 is a glycoprotein. It is reported that some unique glycoproteins are specifically expressed on colon cancer cells, for example, CEA, CCOLl, etc.

By means of immunoblotting, the antigen which was extracted from surgical specimen was detected at the same molecular size as that from SW1116. Faint but significant bands were also found in the extract of some normal colonic mucosa at the same molecular size as colorectal cancer specimens. Therefore, we cannot strictly say that this antigen is specific for only colorectal cancer. But the antigen on normal mucosal cells was found at a very low concentration.

To examine the difference between CEA and the antigen recognized by Mab A7, we used a competing binding assay and immunoblotting analysis. The competing binding assay using RIA showed that Mab A7 did not block the binding of Mab anti-CEA. Moreover, blocking by polyclonal anti-CEA which can react to several CEA-related antigens could not block the binding of Mab A7. Immunoblotting procedure also showed that the antigen recognized by Mab A7 was different from CEA. Moreover, Inatsu et al. recently showed that the antigen recognized by Mab A7 was not absorbed with purified CEA (unpublished data).

As a result, this report indicates the evidence that the antigen recognized by Mab A7 is a unique antigen of human colorectal cancer and may be applicable to the diagnosis and treatment of the colorectal cancer.

\section{References}

1) Colcher, D., Horan, H.P., Nuti, M. \& Schlom, J. (1981) A spectrum of monoclonal antibodies reactive with mammary tumor cells. Proc. Natl. Acad. Sci. USA, 78, 3199-3203.

2) Colcher, D., Horan, H.P., Wunderlich, D., Nuti, M., Teramoto, Y.A., Kufe, D. \& Schlom, J. (1985) Monoclonal antibodies to human mammary carcinoma associated antigens and their potential uses for diagnosis, prognosis and therapy. In : Immunodiagnostics, edited by R.M. Aloisi \& J. Hyun, Alan R. Liss Inc., New York, pp. $215-258$.

3) Cone, R.E. \& Marchalonis, J.J. (1974) Surface protein of thymus-derived and bone marrow derived lymphocytes: Selective isolation of immunoglobulins and O-antigen by non-ionic detergents. Biochem. J., 140, 345-354.

4) Cristophe, G., Angelo, V., Andreas, S.H., Magali, S., Stefan, C. \& Mach, J.P. (1986) Immunochemical characterization of two antigens recognized by new monoclonal antibodies against human colon carcinoma. J. Immunol., 136, 1497-1503.

5) Drewinko, B., Young, L.Y., Leibonitz, A., Barlogie, B., Lutz, D., Jannson, B., Stragand, J.J. \& Trujillo, J.M. (1984) Cellular discriminants for a biological classification of human colon carcinoma. Cancer Res., 44, 4241-4253.

6) Drewinko, B., Young, L.Y., Chan, J. \& Trujillo, J.M. (1986) New monoclonal antibodies against colon cancer associated antigens. Cancer Res., 46, 5137-5143.

7) Ey, P.L., Prowse, S.J. \& Jenkin, C.R. (1978) Isolation of pure $\operatorname{IgG}_{1}, \operatorname{IgG}_{2 \mathrm{a}}, \operatorname{IgG}_{2 \mathrm{~b}}$ immunoglobulins from mouse serum using protein A-Sepharose. Immunochemistry, 15, 429-436. 
8) Firan, P.J., Grant, R.M. \& Mattes, C. (1982) Immunohistochemical techniques in the early screening of monoclonal antibodies to human colonic epithelium. $B r . J$. Cancer, 46, 9-17.

9) Greenwood, F.C., Hunter, W.M. \& Glover, J.S. (1963) The preparation of ${ }^{131}$ I labeled human growth hormone of high specific radioactivity. Biochem. J., 89, 114-123.

10) Haskell, C.M., Buchegger, F., Schreyer, M., Carrel, S. \& Mach, J.P. (1983) Monoclonal antibodies to carcinoembrionic antigen ionic strength as a facter in the selection of antibodies for immunoscintigraphy. Cancer Res., 43, 3857-3864.

11) Hedin, A., Wahren, B. \& Hammasstrom, S. (1982) Tumor localization of CEA containing human tumors in nude mice by means of monoclonal anti CEA antibodies. Int. J. Cancer, 30, 547-553.

12) Herlyn, M., Steplewski, Z., Herlyn, D. \& Koplowski, H. (1979) Colorectal carcinoma-specific antigen: Detection of means of monoclonal antibodies. Proc. Natl. Acad. Sci. USA, 76, 1438-1442.

13) Kotanagi, H., Takahashi, T., Masuko, T., Hashimoto, Y. \& Koyama, K. (1986) A monoclonal antibody against human colon cancers. Tohoku J. Exp. Med., 148, 353360 .

14) Kristensen, E., Lanvard, E. \& Reimann, R. (1976) Humoral immunity in malignant skin melanoma: Isolation of melanoma specific IgG from melanoma metastasis. Eur. J. Cancer, 12, 945-950.

15) Laemmli, U.K. (1970) Cleavage of structural proteins during the assembly of the band of bacteriophage T4. Nature (Lond.), 227, 680.

16) Lindholm, L., Holmgren, J. \& Svennerholm, L. (1983) Monoclonal antibodies against human gastrointestinal tumor associated antigens isolated a monosialoganglioside. Int. Arch. Allergy Appl. Immunol., 71, 178-181.

17) Magnani, J.L., Brockhaus, M., Smith, D.F., Ginsburg, V., Blaszczyk, M., Mithchell, H.F., Steplewski, Z. \& Koprowski, H. (1981) A monosialoganglioside is a monoclonal antibody defined antigen of colon carcinoma. Science, 212, 55-56.

18) Malaya, B., Sunil, K.C. \& Joseph, J.B. (1984) Identification of a human cancer associated antigen defined with monoclonal antibody. Cancer Res., 44, 4528-4534.

19) Powel, A.K., Paul, I.T., David, S.C., Gang, D.K., Steven, I.H. \& James, C.C. (1984) A cytotoxitic monoclonal antibody to colon adenocarcinoma. Cancer Res., 44, 11941199.

20) Takahashi, T., Yamaguchi, T., Kitamura, K., Suzuyama, H., Honda, M., Yokota, T., Kotanagi, H., Takahashi, M. \& Hashimoto, Y. (1988) Clinical application of monoclonal antibody-drug conjugates for immunotargeting chemotherapy of colorectal carcinoma. Cancer, 61, 881-888.

21) Thompson, C.H., Jones, S.L. \& Pihl, E. (1983) Monoclonal antibodies to human colon and colorectal carcinoma. Br. J. Cancer, 47, 594-605.

22) Towbin, H., Staelin, T. \& Gordon, J. (1979) Electrophoretic transfer of proteins from polyacrylamide gel to nitrocellulose sheets. Proc. Natl. Acad. Sci. USA, 76, $4350-4354$. 